\title{
気道平滑筋の呼吸性調節
}

\author{
近藤 哲理 \\ (東海大学医学部第二内科)
}

気道は大気と肺を結ぶ導管であるが，固定径 の管腔ではなく，たえず呼吸性に径の変化をし ている。このような気道径の変化をもたらして いる気道平滑筋の神経調節は未解明の部分が多 い。

\section{1. 気道の神経支配様式}

気道は自律神経に支配されており，交感神経 と副交感神経の分布を受けている。このうち, 気道調節の上でより重要なのは副交感神経であ る。

解剖学的には, 気管上部は上喉頭神経が，下 部は反回神経が分布しており，気管分岐部より 末梢の気道は迷走神経肺枝からの遠心性神経が 分布している1)。これらは迷走神経の枝で, 延髄 に存在する神経核から投射を受けている（図 1)。これらの神経線維は気道周囲に存在する神 経節に達した後に, 線維を替えて気道平滑筋に 分布している。神経節における延髄由来の神経 線維（節前線維）と節後線維間の神経伝達物質 はアセチルコリン (ニコチン受容体) であるが, 節後線維と気道平滑筋の間の伝達物質もアセチ ルコリン（ムスカリン受容体）である（図 2 )。 交感神経系は気道周囲神経節において, 迷走神 経による気道収縮を修飾すると考えられてい る。

この他に, 中枢から気道周囲神経節に向かう 迷走神経線維中には, iNANC (inhibitory nonadrenergic and nonchorinergic) と呼ばれる線維 が含まれており, 神経伝達物質は神経ペプチド である。この線維は気道の弛緩作用を有してお り, 人間では交感神経系の機能が弱いために, 唯一の気道弛緩系と考えられている。

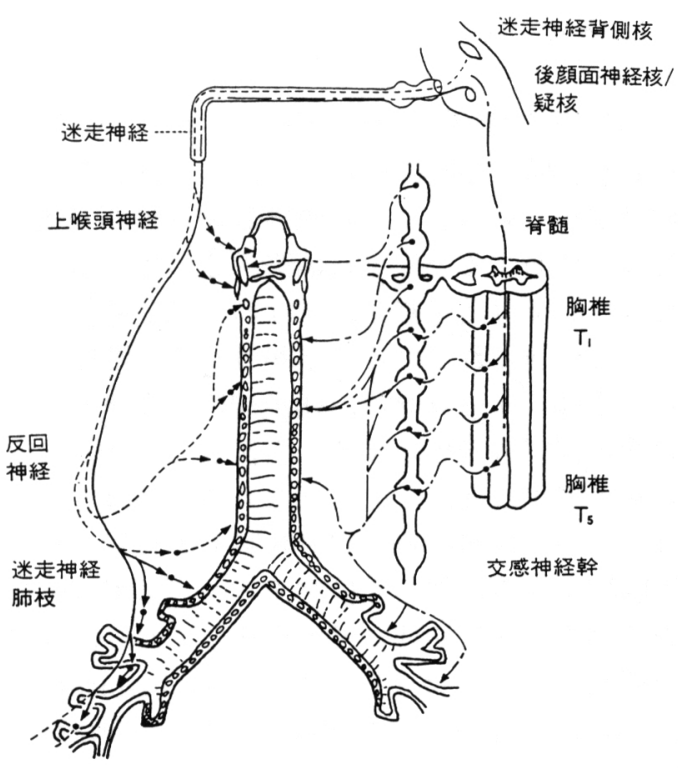

図 1 気道の神経支配線維

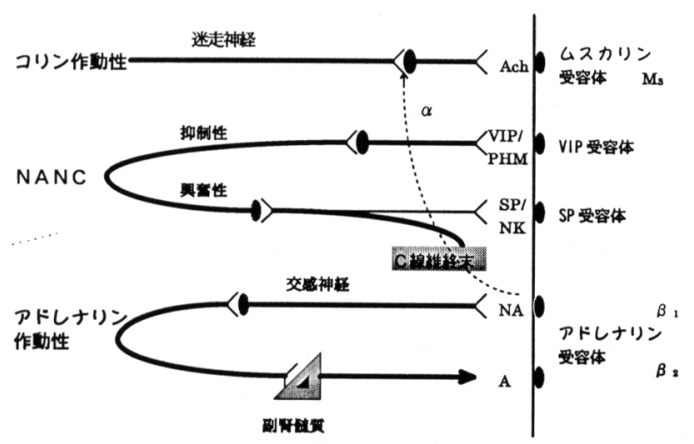

図 2 気道の自律神経支配の様式

\section{2.イヌを用いた気管収縮の検討}

我々はイヌを対象に気管平滑筋の神経調節を 研究してきた2)。図 3 は安静呼吸時の気管平滑 


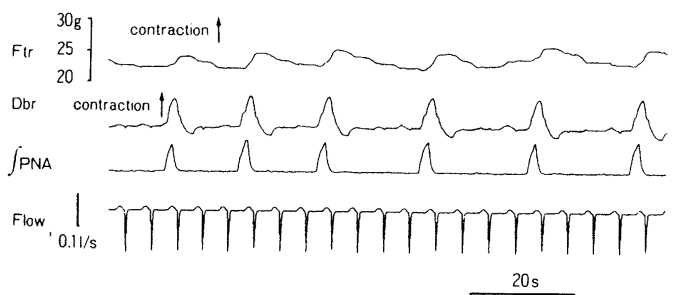

図 3 安静呼吸時の気管 (Ftr) および気管支平滑筋 (Dbr) の収縮弛緩の様相

ともに横隔神経活動（PNA）に同期して収縮 弛緩しているが，気管支のほうが早期に収縮 弛緩を終了する。

筋の収縮と弛緩の様相を示したもので，気管 (Ftr) は横隔神経の活動（PNA）に同期して収 縮弛緩している。この呼吸性収縮は頸部で迷走 神経を切断すると完全に消失するので, 気道の 呼吸性収縮は迷走神経, すなわち副交感神経に よって伝達されていることが分かる。呼吸リズ ムの生成二ューロンは, 迷走神経が発する延髄 の迷走神経背側核と疑核に隣接して存在するこ とを考慮すれば，このような気道の呼吸性調節 は十分妥当性がある。安静呼吸での気管の呼吸 性収縮をさらに詳しく検討すると, 気管収縮は 吸息終末〜呼息初期に最大に達しており，横隔 膜活動でしばしば観察される post-inspiratory inspiratory activity と同様に，呼息初期に肺内 に吸入気を一旦とどめる役割を有している可能 性がある3)。

イヌに $\mathrm{CO}_{2}$ を吸入させると呼吸は速く大き くなるが，気管の周期的な呼吸性収縮は個々の 収縮が癒合して持続的な収縮の様相を示す。

Hypercapnia による呼吸活動の増加時に気管 が持続的収縮をすることは, 換気増加時に導管 径が狭小化するという不合理な結果をもたらし ているが，その理由は明らかではない。

咳嗽は気道内の侵害物質を強力に排泄する動 作であり，大量の呼出をするために横隔膜活動 は増大する。気道粘膜を機械的に刺激して咳嗽 を誘発すると，横隔膜は断続的に大きく活動す るが，気管は持続性に収縮する。この気管の持 続的収縮は横隔膜活動と同期した周期的な増高 がしばしば重畳しており，咳嗽時の気管収縮は 持続性と周期性の両成分が混在していると推定 される。咳嗽時の気道収縮は, 気道を狭小化す
ることによって呼気の流速を高めて，咳嗽効果 を増強すると推定される4。

一方, 下肢からの求心性神経を電気的に刺激 すると, 刺激強度に比例して血圧上昇と呼吸活 動増加, 気管平滑筋の弛緩 (気道拡張) が認め られる。これらの反応が直ちに運動時のシュミ レーションにはなり得ないが, 運動時にも血 压・呼吸反応に加えて気道径の神経性調節が行 われていることを示している5”。

\section{3．気管と気管支収縮の差異}

次いで，換気を障害せずに気道径を測定する 装置を考案して, 安静呼吸での気管と区域気管 支の収縮を比較した。すると, 気管平滑筋 (Ftr) は吸息後期〜呼息早期に収縮するのに対して, 気管支 (Dbr) はほぼ吸息期に限局して収縮をし ていた(図 3 )。気管支平滑筋が吸息相に限局し て収縮する生理的役割には, 吸息時の死腔を減 少させて吸息効率を高める作用や，吸息時の胸 腔内の陰圧への拮抗などが推定される ${ }^{6)}$ 。

気管と気管支の収縮様式の差異をさらに追究 するために，頸部で迷走神経を切断してその遠 位端を断続的にパルストレインで電気刺激する と, 気管支 (Dbr) は刺激に応じて断続的に収縮 するのに対して，気管（Ftr）は収縮が䵉合して 持続的収縮をする傾向が強い（図 4 ）。これは, 既に述べたような咳嗽時の気管の持続的収縮の 機序を説明し得る所見であるとともに，胸腔内 圧の呼吸性変化に絶えず曝されている気管支が より迅速な収縮様式を有していることを示して いる。

しかし, 気管と気管支の収縮様式の差が気道 平滑筋の特性にのみ負うかは疑問が残る。迷走 神経と気道平滑筋間の神経伝道物質 (ムスカリ ン受容体）の拮抗薬であるアトロピンを, 濃度 を漸増しつつ投与すると，気管よりも気管支の 方が収縮は高度であり，気道の部位によってコ リン受容体の数に差があることが示唆され る7)。一方, 気管の支配神経である反回神経気管 枝の神経活動（RNA）を測定すると, 気管収縮 ( Ttr) と同一の活動パターンが観察され（図 5 ), 気道の神経調節は中枢からの下行性指令, 神経筋接合部, 平滑筋の各レベルで多様な修飾 が行われていることが推定された。 


\section{4. 気道の呼吸性調節と疾患}

気道系の障害による呼吸器疾患は多いが，気 道の呼吸調節が直接関与する疾患は知られてい ない。また，肺移植などで胸郭内気道への神経 支配が切断されても，目常生活に多大の支障が ないことから，気道の呼吸性調節は生命の維持 に決定的な役割を持つとは思われない。しかし， 疾患のために気道が慢性的な狭窄状態にある患 者では重大な役割を果たす可能性がある。

気道平滑筋の神経調節が関係する成人疾患に は肺気腫・慢性気管支炎などの慢性閉塞性肺疾 患（COPD）がある。COPD は末梢気道の炎症

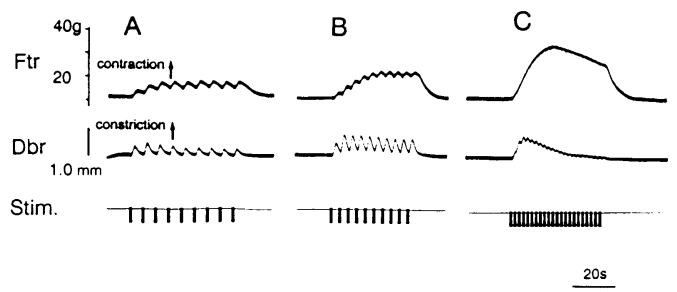

図 4 頸部で迷走神経を切断し，遠位端を断続的に 電気刺激（Stim）すると，気管支 (Dbr) は刺 激に応じて断続的に収縮するが，気管（Ftr） は持続的収縮をする傾向が強い。
性疾患で，気管支喘息とは疾患概念の境界がや や不明確になりつつあるが，薬物治療の第一選 択剤は抗コリン剂とされている(図 6 )。抗コリ
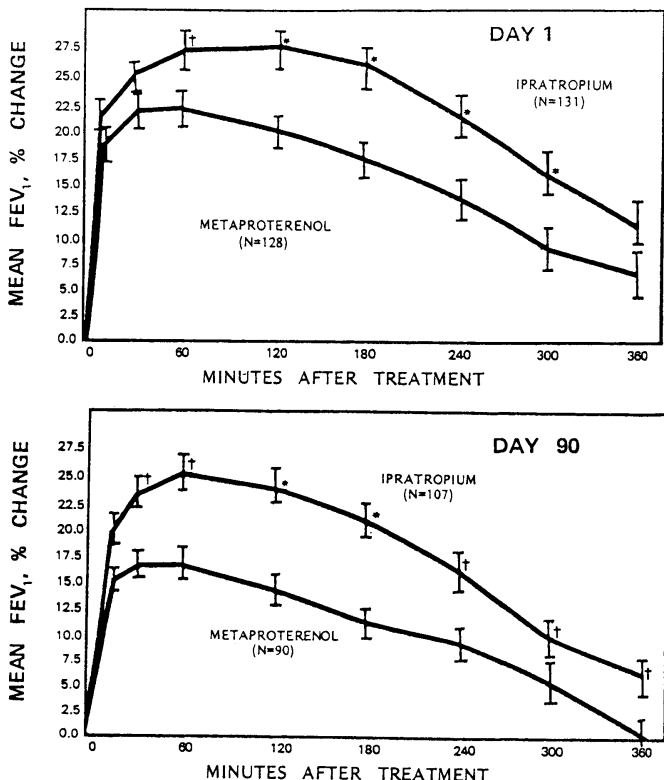

図 6 抗コリン剂は, 肺気腫には $\beta$ 刺激剂よりも有 効であり,連用によっても効果は減弱しない。

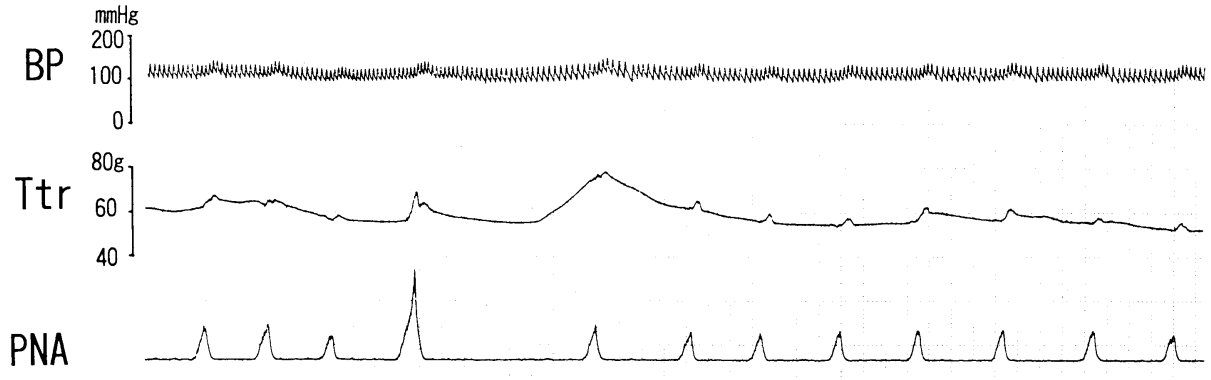

RNA
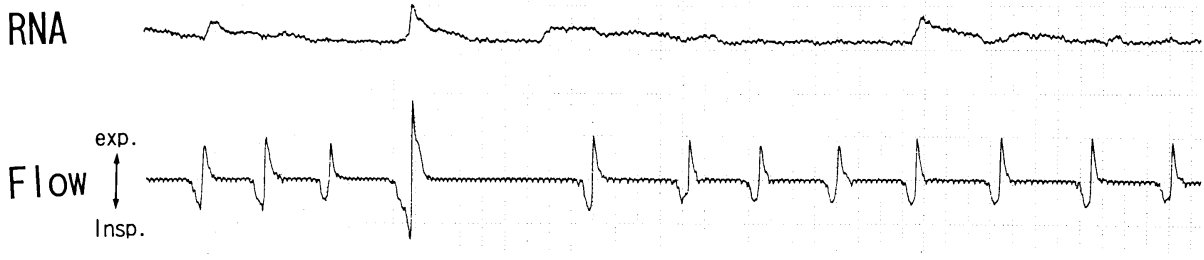

図 5 気道の機械的刺激時（下線）の気道収縮（Ttr）抢よび反回神経気管枝活動（RNA） 
ン剤は, 気道平滑筋上のコリン受容体の分布特 性によって, 末梢気道により強力な迷走神経遮 断作用を呈し, 肺気腫のような末梢気道病変に 有効と考えられている8（図 6)。

小児気道疾患の代表は気管喘息である。自律 神経との関与では, 副腎髄質由来のカテーコラ ミンは交感神経系に分類されるものの, 狭義の 神経調節には含まれない。胸髄ニューロンから の交感神経遠心性線維は直接に気道平滑筋には 作用せず，気道周囲神経節で迷走神経による気 道の緊張を修飾している。 $\alpha$ 受容体の遮断剂で あるフェントラミンで神経節の遮断をしても， 気管支喘息には十分な臨床効果がないことか ら, 喘息における交感神経の役割は否定的であ る。気管支喘息の病態として, 迷走神経線維に 含まれる iNANC系の先天的機能異常が注目 されたが, 期待されたほどの意義はないと考え られる。気道の求心性神経は, 肺伸張受容器, 刺激受容器, C 線維自由終末からの神経線維を 含み, 刺激受容器と $\mathrm{C}$ 線維自由終末からの入力 は咳嗽, 呼吸促迫などを発生する。C線維終末 からの無髄線維は気道刺激に対して逆行性に夕 キキニンを分泌して, 局所での気道収縮を発生 させ (軸索反射), 気管支喘息発症の重要なメ力 ニズムとされているが，これは中枢調節ではな
く局所反射に分類する。

\section{参考文献}

1) 無江季次 : 交感神経系とアドレナリン受容体の 分布. 日本臨床 45：1680-1686, 1987.

2 ) 近藤哲理：気道平滑筋の呼吸性調節。呼と循 $43: 1157-1162,1995$.

3 ) Kondo T, Kobayashi I, Hirokawa Y, et al. : Centrally driven slow oscillatory potential of extrathoracic trachea. J Appl Physiol 74: 1066-1072, 1993.

4) Suzuki I, 近藤哲理, 小林一郎・他：咳嗽時の イヌ気管平滑筋の神経調節。 日胸疾会誌 33 : 23-28, 1995.

5 ) Kanazawa O, Kondo T, Kobayashi I, et al. : Tracheal, circulatory, and respiratory responses to femoral nerve stimulation. Jpn J Physiol $46: 319-325,1996$.

6 ) Kondo T, Kobayashi I, Hirokawa Y, et al. : Differences in tracheal and bronchial smooth muscle in dog. J Auton N Sys $55: 1-8,1995$.

7 ) Shioya T, Pollack ER, Munoz NM, et al. : Distribution of airway contractile responses in major diameter airways of dogs. Am J Pathol 129 : 102-108, 1987.

8 ) Tashikin DP, Ashuyosh K, Bleecker ER, et al. : Comparison of the anticholinergic bronchodilator ipratropium with metaproternol in chronic obstructive disease. Am J Med 81 (suppl) : 81-90, 1986. 